\title{
Young FutUre AfricA - IMAGES, IMAGINATION AND ITS MAKING: AN INTRODUCTION
}

\author{
Jeannett MARTIN, Christian UNGRUHE \& Tabea HÄBERLEIN*
}

\section{INTRODUCTION}

TO BEGIN WITH SOME GENERALISED OBSERVATIONS, when talk is of the future, children and youth never seem to be far off. Apparently, for a good reason. For how can we imagine the future without them? In common public discourses, it is often said that "children are our future", but for generations, doubts have been expressed about whether "today's youth" will be able and willing to creatively shape the future. This doubt is indicative of what society expects from children and young people: while they may be seen as carriers of political and economic achievements and the existing social order, they are, after all, the symbol of new horizons, change, and of a brighter and better future. However, such expectations are also often bound up with worries concerning the future prospects of children and young people. Perhaps this has always been so (Lindenau 2009: 9f). But the pace at which social, economic and political changes are currently taking place in the world, while bringing new advances and opportunities, also brings feelings of insecurity and fear of an uncertain future.

This field of tension between uncertainty and hope with respect to young people and the future is possibly a cross-cultural phenomenon. However, it is perhaps nowhere as palpable as in Africa. There, the special significance of children and youth is clear for demographic reasons. Around two thirds of the population of the "young continent", as it is often called in political and academic discourses, are under 35 years old and thus count as children and youth, according to the definition of the African Union (AU n.d.; AU 2006: 3). Hence, nowhere is the future younger than on the African continent. In turn, nowhere else do young people face a future so ambivalent and uncertain. Armed conflict, terrorism, political instability and nepotism, HIV/AIDS, the challenges of climate change and economic decline are widespread in many countries (Zack-Williams, Frost \& Thomson 2002). All produce obstacles which seem to rule the present and future lives of many - and particularly young - Africans for whom "uncertainty has become a dominant trope of life" (Cooper \& Pratten 2015: 1). Thus, many studies of children and youth in Africa tend

\footnotetext{
" Jeannett Martin, Social Anthropologist, Postdoc, Centre for Interdisciplinary Research (ZiF) Bielefeld, Germany, jeannett.martin@uni-bayreuth.de; Christian Ungruhe, Anthropologist, Postdoc, Department of Public Health, Section for Sport Science, Aarhus University, Denmark, cu@ph.au.dk; Tabea Häberlein, Social Anthropologist, Postdoc, Chair for Social Anthropology, Bayreuth University, Germany, tabea.haeberlein@uni-bayreuth.de
} 
to reproduce notions of hopelessness, decline and a bleak future (Cruise O'Brien 1996; Honwana 2014).

On the other hand, today's children and youth are perceived as the hope for Africa's future, a generation which is seen as having the potential to overcome social, political and moral decline and break new ground in order to find a place in (a better) society (Diouf 2003; Masquelier 2005). Emerging middle classes in African cities, increasing political engagement in totalitarian states, and spaces of economic and cultural creativity in urban spheres serve as examples of this (Spronk 2012; Kirschner 2010; Perullo 2005).

While analyses of African children and youth as a generation of either hope or decline have added important insights, such studies often speak of, and for, young people without taking their explicit engagement with the future into account. We believe that in order to paint a more differentiated picture of childhood, youth and future in Africa, we need to study the young generation from its own perspective; the ideas, expectations and concrete practices of young people with regard to their future. Children and young people not only have a role to play in the near and distant future, they also formulate their expectations in the present, and thus contribute to shaping the future (see e.g. Prince 2005 for young Hip Hop activists in Kenya and Shahine 2011 for the rising political engagement of youth during the socalled Arab Spring). In stressing in particular how the future is shaped and fought for by young Africans in contemporary contexts, we take up Jennifer Cole's and Deborah Durham's remark that the future is always projected - in the sense of "throwing forward", as well as in the sense of having a life "project" (2008: 21). With our particular view of children and young people as designers and negotiators of the future, we further follow Michaela Pelican's and Jan Patrick Heiss's interest in "making a future" and how it is "confronted and constructed through action" (2014: 7).

This perspective does justice to a point which is essential in the context of future: change. Individual and collective images and ideas of how the future will be are not static, but are always embedded in political and economic conditions and social relations that are dynamic and can also be influenced by the actors themselves. This does not mean that the future has to be different from the present or the past per se; and negotiating the future does not necessarily mean breaking with existing orders or relations, for example between the generations. Rather, continuity is important on many levels. We understand continuity and change as an expression of dynamic negotiation processes, and it is these processes which seem to us to be central to an understanding of childhood, youth and future.

All contributions to this volume engage with such dynamics. Senni Jyrkiäinen and Victoria Bisset discuss the significance of modern ideas of love in times of internet use among educated young people in urban Egypt; Sabrina Maurus (southern Ethiopia) and Wolfram Laube (northern Ghana) look at how schoolchildren's images 
of the future are affected by state policies and global discourses of childhood and development, while Silke Oldenburg examines university students' hopes of participation in a modern future in the context of the unresolved armed conflict in the east of the Democratic Republic of Congo. While the authors focus on different age groups (from about ten-year-old children to young adults in their twenties or even thirties), they all show that the ways in which the future is imagined, and how young people attempt to realize it, are embedded in various dynamic social relations, particularly between and within generations (see Cole 2010; Masquelier 2010; Weiss 2009). Hence, the course of young people's attempts to shape the future is not linear and one-dimensional, but a dynamic search for and negotiation of promising opportunities to achieve their goals.

Considering this, childhood and youth are not reduced to a symbol of either hope or decline, as referred to above, nor are they understood as a synthesis between these poles and placed in a "both-and" category, as suggested by many recent prominent studies. In addition to authors who describe young people in Africa in dichotomous terms, as vanguard or vandals (Abbink \& van Kessel 2005), promise or peril (Muhula 2007), makers and breakers (Honwana \& De Boeck 2005) or hooligans and heroes (Perullo 2005), we understand childhood and youth rather as relational categories which contain different meanings in different relational constellations (Durham 2004): the way children and young people negotiate and shape their ideas of the future will differ, depending on whether they are interacting with their peers or with their parents, whether they are doing it at school or at home, in private or in public spheres.

Therefore, and in view of the fact that meanings change in the course of time, we refer to childhood and youth as specific and dynamic life phases as suggested by Prout and James (1997: 8). The relationality and dynamics of childhood and youth make it difficult to establish generic, unambiguous categorizations. From an anthropological perspective, what are often assumed to be universal phases of biological and psychological development, or globally applicable legal norms, do not provide adequate classification criteria. In order to acknowledge the specific and dynamic social, cultural and historical dimensions as well as the changing anthropological perspectives, we apply a rather broad definition of childhood, children and youth/s. Hence, we refer to young persons who have not reached social maturity in their society and whose access to resources, whose experiences, representations, practices and objectives relate to their specific positioning and selfascertainment within (different and sometimes overlapping) social orders (Montgomery 2009: 53; Pache Huber \& Ossipow 2012: 27).

In this, the need to differentiate between children and youth becomes apparent. As a widespread practice, childhood is characterized by social, legal and economic dependence on adults, and under many circumstances, children are not expected to observe social norms and obligations, religious and ethical values, or to take over 
economic and legal responsibility, in the same way as adults. Youths and young adults may also be dependent and involved in social learning processes, but in comparison to children they often have more responsibilities and obligations, a more nuanced consciousness of their own social, political and economic ambitions and usually a greater degree of autonomy and ability to act. However, these differences are neither universal nor do they create fixed and non-overlapping categories of children and youth. Rather, they are also dependent on and subject of negotiation in the realm of categories like gender, class and religion, to name a few (Ungruhe 2015: 37f).

Our anthropological interest is directed towards young people's socio-culturally and temporal informed images, imagination and making of the future, as well as their causes and consequences. In this, we are less interested in young people's short term perspectives but in perceptions, negotiations and constructions of their life trajectories directed towards their future lives as adults. Additionally, this volume focuses particularly on the influence of education, as this is prominent in all the contributions. With education we refer to a Western-type education in shaping young people's (engagements with their) futures. ${ }^{1}$

Certainly, there are other important dimensions such as the prospects of religion (e.g. Pentecostal churches and Islamic reform movements; see Bochow 2008: 338-340; Masquelier 2007; 2010) or migration (internally or transnational; see Rodet \& Razy 2016) which shape young people's approaches to and perspectives of the future. By stressing on Western-type education as a lens to understand children's and youth's images, imagination and making of the future, however, we show how their understanding and negotiation towards it is a dynamic (and often conflicting) process fueled by existing local conceptions (e.g. continuity and reproduction of the social order) and globally circulating ideas of the future (e.g. progress and individual success). While the articles in this volume approach this in different ways and on various levels and shed light on children and youth at different stages of their lives, on male and female perspectives, on rural and urban livelihoods, and with reference to various topics across different regions of the continent, we will identify and outline commonalities in this regard beyond the specific local and regional aspects.

\section{IMAGINATION AND IMAGES OF FUTURE}

What do we mean when we put emphasis on young people's imagination? Imagination as a concept has been approached from different disciplinary angles,

\footnotetext{
${ }^{1}$ By taking Western-type education as point of departure for young peoples' engagements with the future we do not refer to the notion of a single global school culture which has allegedly shaped uniformed images and visions among children and youth in the world (see Anderson-Levitt 2003). Rather, we focus on the influences that Western-type education entails (such as a belief in individual success and progress) and how these are appropriated in local African settings.
} 
while the respective meanings may differ considerably. ${ }^{2}$ Jean-Paul Sartre (1948) describes imagination as the human capacity to withdraw from everyday life, while others see it as a creative practice and related to the realms of art and aesthetics (Kant 1964: 138, following McLean 2007: 5). Maurice Godelier (2015) assumes that imagination ("l'imaginaire") is an activity to represent realities which do not exist, did not exist and will maybe never exist and thus relates it to the domain of the unreal. Yet, the unreal can become real for those who believe in it.

Anthropological studies show how imagination is related to several of such "unreal" domains, e.g. to the nation (Anderson 1983), to tradition (Hobsbawm \& Ranger 1983) and even to ethnography (Hastrup 1995) or - as in this issue - to future. Imagination towards the future is both source and object of images of the future: imagination needs images and images are also the result of imagination. While we refer to images as mental representations of objects or ideas (Förster, under review), we understand imagination as a human capacity and as a socially embedded individual practice - a practice which is influenced by collectively shared images and itself producing those images (Appadurai 1996; Förster, under review). Hence, imagination towards the future may contribute to form social reality. More than just idiosyncratic flight, fantasy, pastime or sheer individual ambition, we regard imagination towards the future as social negotiation of the possible.

However, among today's young generation in African settings, hopes for the future seem to be increasingly individualized - not least due to increasing processes of globalization and the circulation of images of individual progress and success. This is also reflected in the studies of this volume. When Laube speaks of "aspirations", Maurus of "visions" and Jyrkiäinen and Bisset of "expectations" (while only Oldenburg refers to "imagination") they address this notion of personal achievements among young people. Nevertheless, as these studies also show, aspiring, expecting or imagining individual progress and success may relate to shifting meanings of subjectivity. Still, existing forms of a rather collective and cyclical notion of life do not disappear but interact with new conceptions of individual and linear understandings. Regarding the future, this points to the conflicting perceptions of time which these understandings involve.

Aleida Assmann (2013) reminds us that images of (as well as imagination towards) the future can also be seen as constituents of overarching time orders or "cultural time regimes". She understands such orders as meaning a "complex of cultural assumptions, values and decisions, which guide human intentions, actions, feelings and construals, without any conscious reflection on the part of the individual" (Assmann 2013: 19). ${ }^{3}$ Here, Assmann underlines the structuring power of

\footnotetext{
${ }^{2}$ For overviews on the debates on imagination see Kearney (1998), McLean (2007) and Förster (under review).

${ }^{3}$ Assmann locates the beginning of the culturalization of physical time in Europe towards the end of the Enlightenment, when abstract terms such as "history" and "future" are used for the first time.
} 
such time orders. At the same time, it is no longer possible to talk of homogeneous, "indigenous", cyclical time concepts as they used to be described by early anthropologists (Evans-Pritchard 1939; Bohannan 1953). ${ }^{4}$ While children's and young people's images of the future as presented in the contributions to this volume are rather embedded in various, interlocking cultural time regimes (Wallman 1992) in which the connotation and meaning of "future" varies accordingly, this may influence their imagination and actions towards the future. It can be assumed that in the life of many young people in Africa there is a co-evalness (or co-temporality) and intertwining of "cyclical" concepts of time (without any strong future orientation) and "linear" concepts (with a strong future orientation), even if these onedimensional and unidirectional models are over-simplified (Wallman 1992: 11). ${ }^{5}$ The influence of the modern ("linear") time regime in societies with e.g. cyclical concepts must be seen in connection with the implementation of colonial power and the raising paradigm of modernization and Western belief in progress after World War II.

With the implementation and spread of formal education in Africa, reinforced by global measures to meet the Millennium Development Goal 2 ("Achieve universal primary education") proclaimed by the United Nations, ${ }^{6}$ a medium was created through which almost all children and young people in Africa today come, more or less, into contact with modern time regimes. The contributions to this issue show how deeply Western formal education has influenced African societies.

From Maurus we learn that children of agro-pastoralists in southern Ethiopia, who have never been to school, imagine their personal future corresponding to the social roles and everyday practices of the previous generations, and the children neither question nor denigrate the agro-pastoral way of life in which they are growing up. Their visions of future are based on a cyclical time model which aims at preserving the existing social and cultural order. For the Ethiopian as well as the Ghanaian context, Maurus and Laube point out how and to what degree these notions differ

Referring to Koselleck (1979), she describes the rise and decline of the modern European time regime, in which belief in God was gradually replaced by belief in progress. This led to the development of a linear understanding of time, together with the idea of a break between past, present and future and an "empathic orientation towards the future" (Assmann 2013: 48, 92).

${ }^{4}$ A more recent example of such a homogeneous concept is Alma Gottlieb's ethnography of early childhood among the Beng in the Ivory Coast. In "The afterlife is where we come from" (2004), she describes a cyclical concept of time in which children are regarded as reborn ancestors who live in a mystical world (wrugbe) until they are born again. After their birth, they live in this world for a time, and ideally return to the world of the ancestors upon their biological death.

${ }^{5}$ Apart from the question of different time regimes, images of future can be located on different time levels which are related to each other in different ways: individual time, family time and historical time (Hareven 1977: 58). Thus, visions of one's family belonging in the future may be different from what is currently the case, seen from an individual perspective (see the article by Jyrkiäinen and Bisset on choosing marriage partners, or Laube on the role of the giver in family gift exchange relations).

${ }^{6}$ For the exact definition of the Millennium Development Goal 2 see:

http://www.un.org/millenniumgoals/education.shtml, retrieved July 21, 2016. 
from those of young people who have been socialized for a number of years in Western-type educational institutions.

As all the contributions show, formal Western-type education is a key source for imagination. In the following, we elaborate on why and how this relationship has become so powerful among today's young people in Africa. Here we shed light on the effects of mass campaigns for education, students' ideas of being modern and successful as well as their dreams to become a social giver and to found a family.

\section{Echoes of mass campaigns and state politics}

The promises made in mass campaigns for education organized by the state and by NGOs are echoed in the future visions of young Africans presented in these contributions. Education frequently appears as the only possible way to a "successful" future. As shown by the authors, education is so closely linked to the image of a successful future that alternative options are hardly considered, or are regarded only as temporary solutions. In the case of Ethiopia, the way Hamar children imagine the future is closely linked to the nationalist development discourses of the state, which play a role in the school curriculum and are reflected in the language used by the pupils. The article by Maurus contains extracts from Ethiopian school books, with arrows and process flows as "dominant basic metaphors" of modern concepts of time (Assmann 2013: 49; Hodges 2008: 417); they illustrate graphically how the Ethiopian state presents the future to its young citizens as a "dependable orientation and glowing promise" on the basis of a modern time regime, while vehemently rejecting the past and tradition (Assmann 2013: 10, 92).

\section{Becoming "modern", breaking with the past}

Following a linear concept of time, young people often imagine different future lifestyles and occupations to the present ones of their parents. Maurus' study among secondary school pupils with an agro-pastoral family background shows that these young people imagine individual careers in which they undertake training and then work in modern sectors, for example as doctors, pilots or engineers. The future they imagine is far beyond their parents' occupational practice of herding or the cultivation of fields. Such an imagination of modernity and change by pupils of a Junior High School (JHS) in a rural area of northern Ghana is formulated by Laube in a similar way. Like the children in southern Ethiopia, many of them belong to the first generation to have a school education. Three quarters of the Ghanaian respondents see themselves working in the public sector, mostly as doctors, nurses or teachers. The majority cannot imagine themselves working as farmers, although most of their families depend on agriculture for a living.

In relation to the role of education and imagined occupational narratives, young people's ideas vary in characteristic ways and are closely connected with the socialization of children in or out of school. Children and young people who have been socialized in Western-type schools frequently describe images of a "modern" 
personal future, linearly conceived educational and professional careers which anticipate a break with the past. The rural lifestyle of their parents' generation is rejected, while a "modern" and "progressive" urban lifestyle is imagined and aspired to. Oldenburg's research among students in the Congolese city of Goma shows how young people construct rhetorical dichotomies by locating themselves and their personal future in a "civilized" urban life and distancing themselves from a rural life they regard as backward. This adds to the observation in various locations considered in the articles of the issue that pupils and students of a Western-type education system see themselves as important wheels of a linearly conceived social development that is moving in the direction of Western modernity.

\section{Clinging to the belief in "success"}

Remarkably, all contributions acknowledge empirical findings which have been described since the 1970s in the literature on schoolchildren and university students in African societies. Young people, even though they often live in difficult conditions and are aware of the lack of jobs and opportunities for earning a living, appear to be unshaken in their belief that going to school and university will help them to rise socially (e.g. Nwagwu 1976; Adick 2003; Spöhr 2010). The contributions also describe how school pupils imagine the future, and their firm belief in the feasibility of their goals. Many are convinced that after completing school or university they will find their dream job and that their formal education will bring better living conditions for themselves and their families. This applies equally to students in the city of Goma in DR Congo, and to schoolchildren from peasant families in southern Ethiopia and northern Ghana (see also Roth 2014 for young educated adults in urban Burkina Faso). For Egypt, higher education seems to be necessary at least in order to have better marriage prospects. Some authors underline the role of culturally influenced ideas of prestige and social status, which make young people cling so tightly to their visions of the future that they sometimes appear to be "outside their historical and socio-political context" (Leavy \& Smith 2010: 7; Roth 2014: 102). We see this in connection with the ideologies that are inscribed into their minds and bodies through a Western-type education and discipline, in the sense proposed by Michel Foucault (1977). ${ }^{7}$

The empirical studies in this issue further suggest that for most young people, social advancement means above all more individual freedom and greater autonomy, while remaining embedded in the idea of family solidarity (see also Blanchard 2014), and that they see education or educational qualifications as the key to achieving this. Oldenburg thus describes education as a collective imagination that offers young people orientation and meaning in their hopes for the future. This finding contradicts the often-quoted image of African youth "in waithood" (Honwana 2014). The young people in the societies of Goma (DR Congo), Ethiopia

\footnotetext{
7 Anthony Simpson (2003) argues in a similar direction in his study of a Catholic mission boarding school in Zambia and the process of students' alienation from their milieu of origin.
} 
and Ghana presented here do not see themselves in such a depressing situation, but are full of hope and imagine for themselves a linear development in the direction of a "modern", and in any case better, future. Certainly, this is not a universal finding which holds for every young person on the continent and it would be important to investigate more in debt in empirical studies, why and in what way the circulating discourse of linear development and progress fuels some young people's optimism towards the future whereas others (as nihilist young jihadis, to point to an extreme example) do not share their view. It may be that while many children and youths in Africa may have ambivalent or pessimistic feelings towards the future, for many others, formal (Western-type) education is still perceived as the "passport to modernity" (Richards 1996: 138), as Oldenburg also argues for eastern Congo. Even if many children of today see their elder brothers and sisters jobless after having completed formal education (see Roth 2014), they still believe in their individual success that is connected with a vision of supporting relatives and developing the country.

\section{Individual success: becoming a giver}

The young people who are receivers today wish to become givers in the future. They very often say explicitly that they want to be able to support their relatives and families. The young people in Ghana and Ethiopia, Egypt and the DRC mentioned in this special issue are underlining this value with their future aspirations. While many schoolchildren and university students paint images of successful individual careers, and reject the lifestyle and social world of their parents, at the same time - and this applies to schoolchildren in rural southern Ethiopia and northern Ghana, as well as to students in Goma in DR Congo - this is followed by discourses of reciprocity and social responsibility and images of future caretakers. ${ }^{8}$ Thus, the idea of becoming someone who is in a position to give is a strong motivation and a driver behind their making of future. Here nothing seems to have changed with the passage of historical time. Nevertheless, the question arises of whether the youth's commitment to supporting their families is a form of emotional and moral self-protection or whether their strategy for employment incorporates concrete plans to share their earned resources. We will come back to this later.

\section{Dreaming of marriage and family}

Western-type education not only fuels the dreams connected to future occupational narratives, but may shape imagination on yet another level. Besides

\footnotetext{
8 There is a theoretical debate on rising individualism in Africa (Marie 1997; 2007; Calvès \& Marcoux 2007). Alain Marie argues that, while in the face of economic difficulties and pauperism, communal solidarity remains an important value and obligation for people in African societies (2007: 179), its character is changing towards a more personalized relation of givers and takers. The question of whether and how today's young people will fulfil this "value and duty" in future, when they are in the position to give and, whether they act more individualistic than the generations before (as Marie 1997; 2007 suggests), remains to be analysed.
} 
planning a professional career, marriage and founding a family are an important part of the future visions of young Africans. Since this is related to different role models, gendered perspectives become very visible, showing different approaches and visions at some levels. As Jyrkiäinen and Bisset show for urban, post-revolutionary Egypt, romantic relationships and freedom to choose one's marriage partner play an important role in the imagination of university students. While social media have contributed to the spread of ideas of romantic love, universities and the internet offer opportunities for meeting age-mates of the opposite sex and forums for exchange. Yet very few of the students expect that they will be able to realize their visions of romantic love and marriage in practice. This may be due to parents' pressure to marry according to their choice and also because many young people themselves stress the importance of marriage as a means of economic security. Hence, the dream of romantic marriages between recent university graduates often remains a dream since many of them continue to be economically dependent on their parents after leaving university.

Marriage and social reproduction are also important future prospects among young people in southern Ethiopia. However, as Maurus argues, whereas female boarders hope to be able to choose their future marriage partners themselves, boys tend to agree to their parents' choice of their first wife while aiming to choose their second wife themselves. While both male and female students in northern Ghana acknowledge existing gender role models in the realm of marriage, they are open to "modern" influences such as single marriages as Laube illustrates (which may also relate to changing role models on other levels such as increasing occupational ambitions among young women). Among young women in eastern Congo, marriage is a determinant of social security and mobility. As Oldenburg argues, for them, higher education is a means to get in contact with potential marriage partners who could provide this (whereas young men rather use their time at a university not least in order to establish contacts with "big men" and climb the social ladder through these networks).

Hence, young people's imagination towards marriage and social reproduction is also part of their future vision in Africa. In some of today's African societies, the choice of marriage partners is often a field of inter-generational tension, especially in view of the spread of ideas concerning universal women's and children's rights (Archambault 2011). Those ideas are present in schools, even in remote rural areas, and influence the imagination and images of young people. Here, tensions result also from the clash of different conceptions of subjectivity and social development.

To summarize, by imagining a successful future, formalized education appears as the vehicle to individual and social success. However, while mass campaigns shape pupils' and students' vision of becoming an important part of a "modern" society in the future, success is still related to the existing social pattern of becoming a responsible person who is in the position to give and care for his or her family. In this way, young people may dream of breaking with the past in order to achieve personal 
goals. Nevertheless, turning this into practice is not least a matter of social negotiation and directly connected to individual questions of identity: Who do I want to be? What role do I want to play in my family? What position do I want to have in society?

This leads to the question of agency and how challenged and conflicting imaginations towards the future could be turned into practice. As Förster (under review) argues, imagination is strongly related to agency since "[w]ithout imagining what we aim at, without being able to imagine a possible future, we would not act at all". However, whether children and young people control their own future (or future plans) is subject to various social dynamics such as class, social affiliation and the degree of economic means of one's family as well as political, gendered and intergenerational power relations (for a historical case study see Bryant 2016). Still, as Evers, Notermans and van Ommering (2011: 12f) rightly argue in relation to children's agency in Africa, "[...] power is not the privilege of the dominant class but rather it is also exercised by those who are dominated", namely by young people themselves. Hence, young people in many African settings may be challenged by and caught up in different kinds of power relations. However, they can also make use of their status to exercise agency in a sense of a Scottian "weapons of the weak" (Scott 1985) or deliberately join forces and stress the notion of youth as agents of change to claim their right to turn their imagination, visions and expectations into practice. Nevertheless, this remains a difficult task. In order to elaborate further on young people's ability to act, we shed light on their making of future (of which negotiated images of the future and imagining one's future life are already part of) in the following.

\section{MAKING OF FUTURE}

Pelican \& Heiss (2014: 18) have argued for investigations of the making of future in Africa, and we respond to this call by regarding it through the lens of childhood and youth. We agree with them in defining the making of future as the cognitive and practical future-oriented actions of people. By this is meant a constant "back- and forth process" in which people shape their future through interaction with their environment (Pelican \& Heiss 2014: 7). For most people in African societies, futurerelated practical action, which requires a minimum of economic and social means, is carried out under difficult, uncertain and often deteriorating conditions (Pelican \& Heiss 2014: 13); this applies in particular to young people, and especially children.

The contributions to this volume shed light on the various ways in which the future is made by them. From Oldenburg's study of students in the war-torn city of Goma we learn how young people work on their constructions of future in cognitive and practical ways. Cognitively, they work on the realization of their visions through a firm belief in their personal social advancement and the power of individual abilities, motivations and actions, instead of locating themselves within the existing structures of inequality. Rhetorically, they distinguish themselves from the 
"uncivilized masses" with reference to their own educational qualifications. Oldenburg argues that with their high expectations with respect to their future life, and low chances that they will be able to realize their goals, they construct a "dramaturgische Fallhöhe (dramatic hero's fall)", in other words the risk of a deep social fall. They try to counteract this risk by concrete actions. Thus, in their everyday activities, students are highly flexible, dynamic and "always on the move". As political leaders in ethnic student associations, young men try to extend their social networks and to gain influence and social status. Female students seek an advantageous marriage or follow a strategy of "tactical juggling" with several partners at the same time, in order to come nearer to their visions of a better future. They use education (or educational qualifications) not only as a means of social distinction, but also as an opportunity to come into contact with influential people, such as members of NGOs, politicians or militia leaders. Young people of Goma, who immediately grasp any promising emerging opportunity, follow many different paths at the same time - a practice that Jennifer Johnson-Hanks (2005) has called "judicious opportunism". If such opportunities are offered, and the young people succeed in acquiring a certain amount of economic capital, many of them try to invest in long-term social capital by using it to build up relations of reciprocity.

This is also shown by Laube in his article on northern Ghana, where school and university leavers often pay for the schooling of younger relatives. He describes the case of an educated young man living in town under precarious conditions. Despite having no permanent income and hardly enough to support his own children, he still supports kin-related children in his home village. Laube interprets this attitude as an amalgamation of Christian values, nationalist ideology and local moral values in which great importance is attached to social responsibility and reciprocal relations. Expecting rewards in the long run, this is also a way of making one's future.

But how do young people react when, despite their high motivation and expectations, they see that they will not be able to achieve what they have imagined? The frequent failure of visions of their future is not a new finding, however confirmed by some of the papers. For instance, Laube's study on the careers of former JHS pupils in northern Ghana shows a wide discrepancy between present pupils' visions of the future and the actual situation of former pupils. While about one third continued their education after completing JHS, less than $10 \%$ of the school leavers attained government employment and thus positions which most pupils anticipate.

In the light of those results, the question remains: why do so many rural and urban youth persist in clinging to this myth of education (see also Nwagwu 1976: 114; Roth 2014)? One could argue with Godelier (2015) that, through imagination, the unreal (or unrealistic) becomes real (for those who believe in it). Thus, the unshakable individual belief in personal success through education can be seen as the product of a collective imagination, as a collectively shared image, as a myth which is caused and fueled by NGO and state discourses and reproduced by those 
who have gained access to job positions in the formal sector. Becoming a professional football player abroad (see Esson 2013) is an alternative (or parallel) imagination of this kind, based on the idea of individual ability to succeed, while e.g. winning a green card for the US in the visa lottery is more related to fortune (Piot 2010).

In Laube's setting, the majority of those who were unable or unwilling to continue their education (about one third), worked on the land like their parents, tried to earn a living through petty trading and occasional jobs (about 19\%), or they were "unemployed" (over 12\%). Thus, the majority experience what for Goma is referred to as a "deep fall", a big gap between expectations and reality, which is seen by others as a personal failure. In northern Ghana, young people who fail to achieve their educational and professional goals and return to the land usually experience feelings of shame. Laube argues that in this situation, young, disillusioned people often refer to a local system known as nyuaa, and reinterpret the normative concepts with which it is associated. Through socially acknowledged behavior, such as supporting local reciprocity networks (by participating in ceremonies within the family circle), they are able to achieve a degree of social recognition and status, and thus maintain their self-respect. In this way, young people contribute actively to the reproduction and entrenchment of existing structures.

This can also be seen in the Egyptian case study by Jyrkiäinen and Bisset on the images and visions of young urban people in connection with marriage. While "modern" spaces such as universities and social media may have changed the imagination of young people, marriage remains a family affair. Young men and women are expected to meet social norms, e.g. by marrying according to parental choice. Confronted with dominant gender role models in addition to a lack of financial means, young people find it difficult to turn their hopes into reality. In view of their dreams of romantic love and free choice of partner, but being aware that their chances of realizing this are very limited, girls tend to avoid social contacts with members of the opposite sex. Later, many girls or young women, but also men, accept the spouse chosen by their families and agree to an arranged "living-room marriage", which means that they follow existing marriage patterns and reproduce dominant social structures.

But young people also contribute to processes of social change through their practices. Thus, many young Egyptians today use social media and have "online relationships". Others avoid social control by their families through secret meetings on the campus or in town. Some young women resist the pressure of their families by pursuing their own career and refusing to marry, even if this means being subjected to social sanctions, such as being labeled a "spinster". Some of them also use the virtual sphere, for example by writing blogs, in order to share with others their experiences of discrepancy between their dreams and lived reality in the matter of finding a partner, and thus trigger social debates. The great interest stirred up by these blogs is a sign of the need for discussion among young Egyptians. The articles 
in this issue describe in different ways how young people in African societies contribute both to the entrenchment of the social structures and realities in which they live, as well as to their change.

\section{FUTURE PROSPECTS}

What can we learn from young people's outlined images, imagination and making of the future in Africa? Their engagement with the future helps us to understand how the figuration of the future is "symbolized, hoped for, and made" (Cole \& Durham 2008: 21) on various levels: individual practices, negotiation processes within the family, and processes of social change. But above all, young people's engagement is a suitable lens for understanding the various social realities in which they grow up and live. They mirror the social circumstances and processes in which the young people try to locate themselves and their life. All contributions to this volume show how strongly young people with a Western-type school education see the future in terms of progress, and how strongly they hope for a "modern" future, regardless of what their present situation and prospects are like. They have in common that they want to achieve the status of adults and to become caregivers (though it has to be a concern for future studies whether this is a general feature among children and youths in African settings). They see various ways to realize these aims: investment in the acquisition of educational qualifications, seeking advantageous marriage arrangements (or refusing to marry, in favor of concentrating on a career), active social or political engagement, or tactical waiting for the right opportunity (Masquelier 2013; Johnson-Hanks 2005).

As different as these paths may be, they are all characterized by notions which imply the idea of social change. Thus, hopes connected to the future go beyond individual ambitions. As a social practice, in the sense proposed by Appadurai and Förster (see above), imagination contributes to forming social reality - even if the desired changes are not materialized or even fought for. This can mean, as shown for the Egyptian example, that new marriage practices are dreamt of, while in reality conventional patterns are still followed. Whether and why change remains on the discourse level, or whether practices will really change, is a subject for future research.

This discussion and the empirical studies form only a small part of the vast field of childhood, youth and future in African societies. Further empirical research is needed in important areas such as, for example, the future visions of children and young people in the context of religious training (such as in Koran schools or Arabic universities), in view of the loss of large parts of the parent generation, whether due to HIV/AIDS or violent conflicts, and theoretical questions such as the consequences and negotiations of different epistemologies in the life of young Africans. This need also applies to methodological debates concerning the collection and interpretation of data concerning imagination, as neither the process of imagining nor the mental images that it produces are directly accessible (Förster, under review). 
Perhaps this special issue will act as a stimulus to carry out further studies with different thematic foci relating to children, young people and the ways they imagine the future, and how they set about realizing their goals. Such studies need to examine the reciprocal connections and possible dialectics of images, imagination and makings of future, and must go beyond the sobering implications of "waithood" on the one hand, and naive ideas of children and youth in Africa as a "generation of hope" on the other.

\section{ACKNOWLEDGEMENT}

We thank all participants of the workshop "Auf dem Weg: Zukunftsvorstellungen und -perspektiven von Kindern und Jugendlichen in Afrika" at the conference of the African Studies Association in Germany (VAD) in Bayreuth (2014) for their contributions to this debate on children, youth and future in Africa. We are particularly grateful for the anonymous reviewers' comments to an earlier version of this introduction. Our thanks go further to the editors of AnthropoChildren and to Ruth Schubert and Jane Sander for language corrections and translation of texts.

\section{BIBLIOGRAPHY}

ABBINK J. \& VAN KeSSEL I. (eds.) 2005 Vanguard or Vandals? Youth, Politics and Conflict in Africa. Leiden : Brill.

ADICK C. 2003 «Mon Avenir-meine Zukunft. Ergebnisse aus senegalesischen und deutschen Schüleraufsätzen, Zeitschrift für internationale Bildungsforschung und Entwicklungspädagogik 26(1) : 39-46.

AFRICAN UNION 2006 «African Youth Charter», retrieved April 4, 2016: [http://africayouth.org/files/charter-en.pdf]

AFRICAN UNION "Africa's Position on Youth!», retrieved April 4, 2016: [http://africayouth.org/files/africa_position.html]

ANDERSON B. 1983 Imagined Communities: Reflections on the Origin and Spread of Nationalism. London-New York: Verso.

ANDERSON-LeVitT K.M. (ed.) 2003 Anthropologies of Education. A Global Guide to Ethnographic Studies of Learning and Schooling. New York : Berghahn Books.

Appadurai A. 1996 Modernity At Large: Cultural Dimensions of Globalization. Minneapolis: University of Minnesota Press.

ARChAmbault C.S. 2011 «Ethnographic Empathy and the Social Context of Rights. 'Rescuing' Maasai Girls from Early Marriage », American Anthropologist 113(4) : 632-643.

Assmann A. 2013 Ist die Zeit aus den Fugen? Aufstieg und Fall des Zeitregimes der Moderne. München : Hanser.

BLANCHARD M. 2014 « Sending money or purchasing provisions? Senegalese migrants' attempts to negotiate a space for autonomy in long-distance family relations », in M. Pelican \& J.P. Heiss (eds.) «'Making a future' in contemporary Africa » (special issue), Journal des Africanistes 84(1): 40-58.

Bochow A. 2008 «Valentine's Day in Ghana. Youth, Sex and Secrets », in E. Alber, S. van der Geest \& S.R. Whyte (eds.) Generations in Africa. Connections and Conflicts (333-356). Berlin : Lit. 
BOHANNAN P. 1953 "Concepts of time among the Tiv of Nigeria", Southwestern Journal of Anthropology 9(3) : 251-262.

BRYANT K.D. 2016 "'An ardent desire to be useful'. Senegalese Students, Religious Sisters \& Migration for Schooling in France, 1824-1842 », in É. Razy \& M. Rodet (eds.) Children on the move in Africa. Past $\mathcal{E}$ present experiences of migration (31-50). Woodbridge : James Currey (Imprint of Boydell \& Brewer, Ltd).

CAlves A.E. \& MARCoux R. 2007 «Présentation: les processus d'individualisation 'à l'africaine' », Sociologie et sociétés 39(2) : 5-18, retrieved July 21, 2016 :

[www.erudit.org/revue/socsoc/2007/v39/n2/019081ar.pdf]

COLE J. \& DuRHAM D. 2008 «Introduction: Globalization and the Temporality of Children and Youth", in J. Cole \& D. Durham (eds.) Figuring the Future: Globalization and the Temporalities of Children and Youth (3-24). Santa Fe : School for Advanced Research Press.

COLE J. 2010 Sex and Salvation. Imagining the Future in Madagascar. Chicago : University of Chicago Press.

COOPER E. \& PRATTEN D. 2015 Ethnographies of Uncertainty in Africa. Houndmills: Palgrave Macmillan.

CRUISE O'BRIEN D.B. 1996 "A Lost Generation ? Youth Identity and State Decay in West Africa », in R. Werbner \& T. Ranger (eds.) Postcolonial Identities in Africa (55-74). London-New Jersey : Zed Books.

Diouf M. 2003 «Engaging Postcolonial Cultures. African Youth and Public Space », African Studies Review 46(2) : 1-12.

DurHAM D. 2004 «Disappearing Youth: Youth as a Social Shifter in Botswana», American Ethnologist 31(4) : 589-605.

ESSON J. 2013 «A body and a dream at a vital conjuncture : Ghanaian youth, uncertainty and the allure of football », Geoforum 47 : 84-92.

EVANS-PRITCHARD E.E. 1939 " Nuer time-reckoning », Africa. Journal of the International Institute of African Languages and Cultures 12(2) : 189-216.

EVERS S.J.T.M., NOTERMANS C. \& VAN OMMERING E. 2011 «Ethnographies of Children in Africa : Moving beyond Stereotypical Representations and Paradigms », in S.J.T.M Evers, C. Notermans \& E. van Ommering (eds.) Not Just a Victim: The Child as Catalyst and Witness of Contemporary Africa (1-20). Leiden-Boston : Brill.

FÖRSTER T. (forthcoming) "Of Imagination. The Social Production of Images", Current Anthropology.

FOUCAULT 1977 Überwachen und Strafen. Die Geburt des Gefängnisses. Frankfurt : Suhrkamp.

GODELIER M.2015 L'imaginé, l'imaginaire et le symbolique. Paris : CNRS éditions.

GotTLieB A. 2004 The afterlife is where we come from. The culture of infancy in West Africa. Chicago : University of Chicago Press.

HAREVEN T.K. 1977 «Family Time and Historical Time», Daedalus 106(2) : 57-70.

HASTRUP K. 1995 A Passage to Anthropology. Between Experience and Theory. London : Routledge.

Hobsbawm E.J. \& RANGeR T.O. (eds.) 1983 The Invention of Tradition. Cambridge: Cambridge University Press.

HodGES M. 2008 « Rethinking time's arrow. Bergson, Deleuze and the Anthropology of time », Anthropological Theory 8(4) : 399-429. 
HonWANA A. 2014 « 'Waithood'. Youth transitions and social change », D. Foeken, T. Dietz, L. De Haan \& L. Johnson (eds.) Development and Equity. An Interdisciplinary Exploration by Ten Scholars from Africa, Asia and Latin America (28-40). Leiden : Brill.

Honwana A. \& De Boeck P. (eds.) 2005 Makers and Breakers: Children and Youth in Postcolonial Africa. Oxford: James Currey.

JOHNSON-HANKS J. 2005 «When the Future Decides », Current anthropology 46(3) : 363-385.

KANT I. 1964 Critique of pure reason (With an introduction by A.D. Lindsay). London : Dent.

KIRSCHNER A. 2010 "Jugend, Gewalt und sozialer Wandel in Afrika», in P. Imbusch (ed.) Jugendliche als Täter und Opfer von Gewalt (133-174). Wiesbaden : VS.

LEAVY J. \& SMith S. 2010 Future Farmers. Youth Aspirations, Expectations and Life Choices, Discussion Paper 013, retrieved March 16, 2016 :

[http://www.fao.org/fileadmin/user_upload/drought/docs/Youth\%20Aspirations\%20Expectation s\%20201210.pdf]

LINDENAU M. 2009 «Einleitung », in M. Linedau (ed.) Jugend im Diskurs : Beiträge aus Theorie und Praxis. Festschrift zum 60. Geburtstag von Jürgen Gries (9-19). Wiesbaden : VS.

MARIE A. 2007 "Communauté, individualisme, communautarisme: hypothèses anthropologiques sur quelques paradoxes africains ", Sociologie et sociétés 39(2) : 173-198, retrieved 21 July 2016 : [www.erudit.org/revue/socsoc/2007/v39/n2/019089ar.pdf]

MARIE A. (ed.) 1997 L'Afrique des individus. Itinéraires citadins dans l'Afrique contemporaine. Paris : Karthala.

MASQUELIER A. 2005 « The Scorpion's Sting: Youth, Marriage and the Struggle for Social Maturity in Niger », Journal of the Royal Anthropological Institute 11(1) : 59-83.

MASQUELIER A. 2007 « Negotiating futures. Islam, Youth, and the State in Niger », in B. Soares \& R. Otayek (eds.) Islam and Muslim Politics in Africa (243-262). New York: Palgrave Macmillan.

MASQUELIER A. 2010 "Securing futures : Youth, Generation, and Muslim Identities in Niger », in A. Bayat \& L. Herrera (eds.) Being Young and Muslim. New Cultural Politics in the Global South and North (225-239). Oxford-New York : Oxford University Press.

MASQUELIER A. 2013 «Teatime, Boredom and the Temporalities of young men in Niger », Africa 83(03) : 470-491.

Montgomery H. 2008 An Introduction to Childhood: Anthropological Perspectives on Children's Lives. Oxford : Wiley-Blackwell.

Muhula R. 2007 « Youth and Politics in Kenya : Promise or Peril ? », Africa Insight 37(3) : 362-375.

NWAGWU N. 1976 «The vocational aspirations and expectations of African students », Journal of Vocational Education \& Training 28(71) : 111-115.

Pache Huber V. \& Ossipow L. (eds.) 2012 «Les enfants comme enjeux et comme acteurs. Appartenances, relations interindividuelles et logiques institutionnelles/Kinder als Zielgruppe und als Akteure: Zugehörigkeiten, interindividuelle Beziehungen und institutionelle Dynamiken » (special issue), Tsantsa (17) : 19-35.

Pelican M. \& Heiss J.P. 2014 (eds.) «'Making a future' in contemporary Africa. Introdution » (special issue), Journal des Africanistes 84(1) : 7-19.

Perullo A. 2005 "Hooligans and Heroes: Youth Identity and Hip-Hop in Dar es Salaam, Tanzania », Africa Today 5(4) : 75-101.

Ріот C. 2010 Nostalgia for the future. West Africa after the Cold War. Chicago: The University of Chicago Press. 
PRINCE R. 2006 «Popular Music and Luo Youth in Western Kenya : Ambiguities of Modernity, Morality and Gender Relations in the Era of AIDS ", in C. Christiansen, M. Utas \& H. E. Vigh (eds.) Navigating Youth, Generating Adulthood. Social Becoming in an African Context (117-152). Uppsala : Nordiska Afrikainstitutet.

Prout A. \& JAmeS A. 1997 «A New Paradigm for the Sociology of Childhood? Provenance, Promise and Problems ", in A. James \& A. Prout (eds.) Constructing and Reconstructing Childhood: Contemporary Issues in the Sociological Study of Childhood (7-33). London : Falmer.

RAZY É. \& RODET M. (eds.) 2016 Children on the move in Africa. Past \& present experiences of migration. Woodbridge : James Currey (Imprint of Boydell \& Brewer, Ltd.).

RichARDS P. 1996 Fighting for the Rain Forest: War, Youth and Resources in Sierra Leone. Oxford: James. Currey.

Rотн C. 2014 «Entre rêves de grandeur et pragmatisme: les jeunes en milieu urbain au Burkina Faso », in M. Pelican \& J.P. Heiss (eds.) "'Making a future' in contemporary Africa » (special issue), Journal des Africanistes 84(1) : 80-105.

SARTRE J.-P. 1948 The psychology of imagination. New York : Philosophical Library.

SCOTT J.C. 1985 Weapons of the weak. Everyday forms of peasant resistance. New Haven: Yale University Press.

SHAHINE S.H. 2011 "Youth and the revolution in Egypt », Anthropology Today 27(2) : 1-3.

SIMPSON A. 2003 Half-London in Zambia. Edinburgh : Edinburgh University Press.

SPÖHR H. 2010 Zukunftsvorstellungen von Oberschülern in Mwanza, Tansania. Berlin : WeißenseeVerlag.

Spronk R. 2012 Ambiguous Pleasures: Sexuality and Middle Class Self-Perceptions in Nairobi. New York : Berghahn Books.

UNGRUHE C. 2015 « Lasten tragen, Moderne befördern. Wanderarbeit, Jugend, Erwachsenwerden und ihre geschlechtsspezifischen Differenzierungen in Ghana », Unpublished PhD Dissertation, Bayreuth : University of Bayreuth.

WALLMAN S. 1992 "Introduction. Contemporary Futures", in S. Wallman (ed.) Contemporary Futures. Perspectives from Social Anthropology (1-20). London : Routledge.

Weiss, B. (2009). Street Dreams and Hip Hop Barbershops: Global Fantasy in Urban Tanzania. Bloomington: Indiana University Press.

Zack-Williams T., Frost D. \& ThOMson A. (eds.) 2002 Africa in Crisis: New Challenges and Possibilities. London-Sterling, VA : Pluto Press. 